\title{
The effect of the integration of talking toys on preschoolers' vocabulary learning in English*
}

\author{
İngilizce konuşan oyuncakların okul öncesi çocuklarının İngilizce kelime \\ gelişimlerine etkisi
}

\author{
Burcu Güngör ${ }^{1}$
}

\section{Article History \\ Received : 08 January 2018 \\ Revised : 02 February 2018 \\ Accepted : 14 February 2018}

\section{Article Type}

Original Article

\section{Makale Geçmişi \\ Geliş :08 Ocak 2018 \\ Düzeltme : 02 Şubat 2018 \\ Kabul : 14 Şubat 2018}

Makale Türü

Özgün Makale

\begin{abstract}
Appropriate conditions and suitable materials can inspire young children to learn a new language effortlessly. The present study attempted to investigate the effects of English talking toys as teaching materials on vocabulary learning of very young learners (VYL) based on their gender. The study was conducted at one of the public preschools in Yenimahalle/Ankara with 48 five-year old children from two classes. The first group of students was the experimental group and they were instructed using English talking toys as a teaching material. On the other hand, the other class was the control group and was instructed using flashcards. The target vocabulary for this study, which was incorporated into a Vocabulary Checklist Test, was developed after a close scrutiny of the relevant literature (i.e. vocabulary learning in young learners) and examination of the theme-related curriculum employed in the chosen preschool. To assess preschoolers' learning of target words in English, a new Vocabulary Checklist Test was developed by the researcher. The results of a series of t-tests showed that the class instructed with English talking toys performed better on both receptive and expressive/productive vocabulary. The results also indicated that there was not any significant difference between males and females in terms of the effect of English talking toys on preschool children's vocabulary learning. The findings suggest that English talking toys are not only used for entertainment and recreational purposes, they can also be used as teaching material particularly when it comes to teaching basic English vocabulary. The current study contributed to areas such as early childhood education, foreign/second language learning, foreign language testing and evaluation.
\end{abstract}

Keywords: Talking toys, English teaching materials, English vocabulary assessment in early childhood

Öz: Okul öncesi eğitiminde, çocuklara uygun şartların ve materyallerin sağlanması yabancı bir dili kolayca öğrenmelerine yardımcı olabilir. Bu çalışmanın amacı, İngilizce konuşan eğitici oyuncakların bir öğretim materyali olarak okul öncesinde anasınıflarında, İngilizce kelime öğretiminde kullanılmasının, çocukların yabancı dil kelime öğrenimleri üzerinde olumlu etkisinin olup olmadığını cinsiyet değişkenine bağlı olarak incelemektir. Bu çalışma, Ankara'nın Yenimahalle semtinde devlete bağlı bir anaokulunun iki ayrı sınıfında bulunan 48 öğrenci ile yapılmıştır. İlk grup deneysel grup olup, öğretim materyali olarak İngilizce konuşan oyuncaklar kullanılarak ders yapılmıştır. Diğer yandan, ikinci grup kontrol grubu olup, flaş kartlar kullanılarak öğretim yapılmıştır.Veri toplamak amacıyla oluşturulan Kelime Testinin içine yerleştirilmiş kelimeler, gerekli kaynak taraması yapıldıktan sonra ve uygulama yapılacak anaokulunun müfredat programı incelendikten sonra belirlendi. Öğretilmesi hedeflenen kelimeler araştırmacı tarafından geliştirilen resimli kelime testi ile ölçüldü. Uygulanan ttestlerin sonuçları, İngilizce konuşan oyuncakların küçük yaş grubu çocukların İngilizce kelime öğrenimlerinde olumlu etkisi olduğunu göstermiştir. Çalışmanın sonuçları, İngilizce konuşan oyuncakların sadece çocukları eğlendiren bir araç olarak değil, aynı zamanda temel İngilizce kelimeleri öğretmede bir öğretim materyali olarak da kullanılabileceğini göstermiştir. Çalışmanın sonunda, okul öncesi, yabancı dil öğrenimi, yabancı dil testi ve değerlendirme gibi alanlara 1şı tutacak bulgulara ulaşılmıştır.

Anahtar Kelimeler: İngilizce konuşan oyuncaklar, İngilizce öğretim materyalleri, Okul öncesinde İngilizce kelime öğretimi ölçümü

DOI: $\underline{10.24130 / \text { eccd-jecs.196720182255 }}$

\footnotetext{
*Presented as "oral presentation" at 5th International Early Childhood Education Congress. This paper is also a part of Master thesis of Burcu Güngör, titled "The effect of the Integration of Talking Toys on Preschoolers' Vocabulary Learning in English"

${ }^{1}$ Marmara University, Faculty of Education, Early Childhood Education Department, burcugungor02@gmail.com
} 


\section{INTRODUCTION}

Like in most European countries, the implementation of foreign language classes into preschool education has started to become more of an issue in Turkey. One of the two indicators is that the percentage of children learning at least one foreign language has risen almost everywhere especially in private preschools in recent years. The other development is the most recentlypublished National English Language Curriculum (MONE, 2016). Until a year ago, there wasn't an English Language Curriculum stating the goals, contents, instructional methods/materials and evaluation procedures of teaching English to preschoolers in Turkey. For this reason, the teachers introducing English education in preschools could not provide every child an access to an equal education with a basic set of standards of "what" and "how" to be taught. More specifically, English language teachers had difficulty in finding appropriate teaching materials or developing their own materials for their classes (Sert, 2004). Based on this, it can be said that in spite of the efforts for early introduction of English in Turkey, the content, the methods/materials and the ways of transferring knowledge which are suitable for very young learners (VYL) need to be examined by taking their age and characteristics into consideration.

\section{Teaching English to Very Young Learners as a Foreign Language}

As for the "age" factor, Harmer (2007) asserts that age plays a crucial role in what we teach and how we teach it and that's why, a young learner class is different from an adult and/or a teenager class in terms of their learning needs, competences and cognitive skills. Very young learners who are the focus group of the study are defined as those who are aged under 7 years in the literature (Harmer, 2007 and Ersöz, 2007). Similarly, in the English Curriculum designed by MONE (2008), the term "young learner" refers to children from seven to twelve of age. MONE (2006) mentions the possibility of starting to learn English at a younger age such as three to six in some cases and describes this age group as VYL who have distinctive features.

As it is well known that there are some periods during childhood such as breast-feeding period, formula feeding period, periods that children eat by using spoons like adults, at the same time there are also some periods that they even bite off rigid dishes with their teeth. Conscious parents about these periods feed their children with appropriate food according to discrepancy in children's feeding period. This discipline about feeding can be applied for children's foreign language learning process. According to children's age and characteristics "what should be taught" and "in which way it should be taught" show an alteration; that's why, the depth of the language knowledge and the way or style of presenting it should be changed. Like the conscious parents, English teachers, early childhood educators, linguists and researchers who contribute 
to children's foreign language learning by dishing up appropriate knowledge with attractive and effective materials according to their level should try to find answers to "which component of English should be taught in early childhood?" and "in which way should it be taught?" by taking the characteristics of preschool children into consideration. With regard to this, Siraj-Blatchford and Clarke (2000) state that early childhood professionals, language teachers and researchers have a vital role in ensuring that children are exposed to as many positive language experiences as possible to learn a foreign language. At this point, this study tries to present some basic English vocabulary at an earlier age through English talking toys that have been always an ally for children.

\section{The Place of Vocabulary in Foreign Language Teaching}

In teaching English to VYL, in the first place, the emphasis should be on teaching vocabulary which is the crucial component of learning a foreign language. Based on this, Celce-Murcia and Rosensweig (1979) claim that vocabulary should be recognized as a central element in foreign language instruction at early stage. Due to the characteristics and learning style of VYLs who are mostly illiterate and who are English learner as-a-foreign language (EFL) students in a non-English speaking country, it is necessary for them to start to learn a foreign language from vocabulary. Laufer and Hulstijn (2001:3) summarize what to teach first to the VYL by stating that "all language learners are well aware of the fact that learning a target language starts with the learning words".

As for the classification of vocabulary development, in the field of foreign language learning, Melka (1997) suggests that it could be sub-categorized as receptive vocabulary and productive vocabulary development. Receptive vocabulary involves the recognition of a concept or meaning of a particular word while productive vocabulary, a more cognitively demanding task, requires the retrieval and verbalization (i.e. production) of a particular word (Schmitt \& McCarthy, 1997). Children in the initial stages of learning English as a foreign language tend to have greater knowledge of the meaning of words spoken to them when compared to the words that they are able to produce.

In the light of this background, it is critical to understand how VYL learn English vocabulary and which teaching materials are more effective for them. Demirel's research (2004) also pinpoints to the enormous demand for high quality language teaching and language teaching materials in Turkey. According to The Natural Approach, developed by Stephen Krashen and Tracy Terrell in the late 1970s and early 1980s, teaching materials that meet the needs of the young learners (YL) are pictures, realias and toys which are visual. Nation (1990) also lists 
pictures from books, photographs, flashcards, pictures, objects or a cut-out figure which are visual as basic materials that can be used by teachers to explain the meanings of the new words to adult as well as YL or VYL in language classrooms. Among these, flashcards are the commonly used materials for young learners to teach vocabulary. In regard to this, Hopewell, McLaughlin and Derby, (2011) state that flashcards have been employed generally to teach young children. Apart from flashcards, in this study, "talking toys" that have the ability to engage VYLs with playfulness, education, and conversation are considered as audio-visual teaching aids and examined. One of the reasons why talking toys are selected as the focus of the study is that working as an English teacher in a private preschool where only flashcards and photographs are used to teach English words, the researcher has observed that children fall short of constructing the meaning and the purpose and VYL are unwilling to learn and use language because of the lack of the enjoyment and fun. Regarding this, Keddle (1997) and Scott and Ytreberg (1990) indicated that flashcards do not provide learners to hear, see and experience together for effective learning and YL's comprehension. Another reason is that they are not given place in the literature concerning language teaching materials despite the advantages they can bring to the classroom by providing more exposure and more experience with the target vocabulary and helping VYL to practice in different times and places. Cameron (2005:84) emphasized the importance of practice by stating that "vocabulary needs to be met and recycled at intervals in different times and contexts in early language learning stage".

It is a common belief that play is children's work (Piaget, 1981) and children develop physically, intellectually, linguistically, emotionally and socially through toys, games and the imaginative use of equipment and materials (Rivera, 2009). Based on this, talking toys are selected as practical, entertaining and educational language materials to present some basic target words in the classroom. Another significant reason why the researcher has decided to prefer English talking toys for foreign language teaching is that very young learners focus their attention for a long time with game-like activities and attractive materials without losing their attention easily. The role of toys sounding some English words and sentences is not limited to entertainment for children. Talking toys are useful in teaching some basic words and structures in target language by attracting children's attention and practicing them with fun and entertainment. One of the advantages of these "linguistic toys" as teaching materials in foreign language learning process (Espinosa, 2003) is that they help VYL guess most of the vocabulary items from the familiar context enriched with extra picture clues. In addition, they are better involved in the process due to the feeling of security and entertainment to be able to discover the sounds and the picture 
in the toy. They can also impact significantly on preschool children's attitudes toward their English learning and their English vocabulary learning to a certain extent. Furthermore, they may be really helpful in teaching English words at the early stages because children are intrinsically motivated to play with toys and they can be used as one of the main means for teaching (Singer \& Singer, 2005). Most importantly, "English talking toy" can enable VYL to have more enjoyment and more authentic language use in foreign language learning process. Due to the VYL's limited language skills and scarce vocabulary knowledge in target language at the beginning, educational and enjoyable English talking toy can be very effective in providing some basic English vocabulary by creating the context for comprehensible input (Krashen, 1998). Based on this, Krashen's Input Hypothesis (1989) that assumes vocabulary learning takes place so long as the appropriate teaching materials or environmental ingredients are provided is taken as the base in this study. Within these perspectives, this study aims to examine the effects of the integration of English talking toy as a teaching material on five-year old children's English receptive and expressive vocabulary learning.

\section{Research Questions}

The research questions examined in this study are:

1. Is there any difference between preschool children instructed through English talking toys and flashcards in their receptive English vocabulary?

2. Is there any difference between preschool children instructed through English talking toys and flashcards in their expressive English vocabulary?

3. Is there a difference between males and females in terms of the effect of English talking toys on preschool children's vocabulary learning?

\section{METHOD}

\section{Participants}

Forty-eight children who were 5-years-old from a public preschool in Ankara, Turkey participated in this study. The participants received two 40-minute lessons per week and did not have any English instruction other than at school. Two intact classes (morning and afternoon) were used as experimental and control group. To ensure that children both in the control and treatment groups were equal in terms of their English background, a public preschool which doesn't offer English lessons to their students were included in this study. Furthermore, the pre-test was applied before starting to treatment and their parents were 
interviewed about children's English language learning experiences. On this basis, the two groups can be regarded as homogenous groups in terms of their English language experiences.

\section{The Research Method}

This study was formed as a quasi-experimental pre-test - post-test design. The two groups received two different types of treatment:

1. The experimental group was instructed with English talking toys

2. The control group was instructed with flashcards

The lesson plans which consisted of the same activities, methods and strategies apart from the teaching materials were related to the recognition stage of vocabulary learning and the activities in the last part were based on the productive vocabulary learning. The content was about vehicles (i.e., bus, car, police wagon, train, airplane, steamboat, helicopter, bicycle, motorcycle, fire-engine) which was in alignment with 5-year-old preschoolers' curriculum. The length and duration of the intervention (six consecutive class hours during three weeks) were held constant for the experimental and control groups. All the lessons for the three groups were taught by the researcher. All the treatment classrooms were video- and audio-recorded in order to investigate the instructional processes.

\section{Talking Toy: Musical Carpet}

The talking toys are a kind of electronic toys that provide children to hear the sounds of some basic words and to practice them with fun and entertainment (Espinosa, 2003). Espinosa (2003) also represents the talking toys as "linguistic toys" that facilitate the learning of language by making the language attractive and accurate. These toys which are interactive, user-friendly were adapted into the language learning process with a well-designed plan in the experimental group to examine their effects on children's receptive and expressive vocabulary in foreign language learning process.

\section{Data Collection Instruments}

For the purpose to measure children's receptive and expressive vocabulary learning on a specific subject, Picture Vocabulary Checklist Test was designed. It was two-stage tests for receptive and expressive parts and each part comprised 10 questions. In receptive part, the pictures were presented in a multiple-choice format of three pictures per item and VYL were asked to point the correct one among them. On the other hand, in the expressive part, the pictures were presented individually and VYL were asked to recall them correctly. Prior to the main data 
collection, a pilot study was run to verify that the vocabulary checklist test was valid and reliable. The researcher obtained official permission from University Ethical Commission and MONE before administering the research.

\section{Reliability and Validity}

First of all, initial piloting was carried out with three experts' approval to ensure high reliability and validity. Based on this, the experts were asked about the quality and suitability of the test to measure VYL's foreign language vocabulary knowledge. As a result of the feedback received from them, the researcher made the necessary corrections and improvements. Secondly, for final piloting, the vocabulary checklist test was administered to a group of 87 preschoolers who were 5 years old in a private preschool. The aim of the piloting was to see the applicability of the lessons and to try to ensure reliability and validity. Lastly, the Cronbach's Alpha was calculated for receptive and expressive vocabulary parts of the checklist test. The Cronbach's Alpha coefficient was found to be above 0.7 which is acceptable (the Cronbach's Alpha for receptive vocabulary $=, 840$ and Cronbach's Alpha for expressive vocabulary $=$, 905). Therefore, the scales can be said to have acceptable internal consistency.

\section{Data Analysis}

As for the analysis of data, the checklist was analyzed using a descriptive statistic. Each correct answer in the tests was counted one point while the wrong was zero. The maximum score of the test was 20. After the results were obtained, they were analyzed by t-tests in SPSS 18.00. Moreover, the multivariate analysis of variance was conducted to test the impact of gender on VYL's receptive and expressive vocabulary learning with English talking toy.

\section{RESULTS}

In this chapter, descriptive statistics related to Receptive Vocabulary Pretest Scores (PREREC), Expressive Vocabulary Pretest Scores (PREEXP), Receptive Vocabulary Posttest Scores (POSTREC) and Expressive Vocabulary Posttest Scores (POSTEXP) of children for both experimental and control groups were presented.

Table 1. Descriptive Statistics of the PREREC / PREEXP and POSTREC / POSTEXP

\begin{tabular}{lllll}
\hline Variables & Treatment & $\mathbf{N}$ & $\mathbf{M}$ & SD \\
\hline PREREC & Experimental & 24 & 1,75 & 1,03 \\
\hline
\end{tabular}




\begin{tabular}{lllll}
\hline \multirow{2}{*}{ PREEXP } & Control & 24 & 1,7 & 1,26 \\
& Experimental & 24 & 0 & 0 \\
& Control & 24 & 0 & 0 \\
\hline \multirow{2}{*}{ POSTREC } & Experimental & 24 & 9,70 & 0,46 \\
& Control & 24 & 9,25 & 0,84 \\
POSTEXP & Experimental & 24 & 9,29 & 0,75 \\
& Control & 24 & 6,16 & 1,23 \\
\hline
\end{tabular}

When the mean scores of the POSTREC and POSTEXP of the experimental and control groups were examined, it was seen that children in both groups outperform in receptive part than expressive part. This was the indicative of the fact that recognition stage comes before the production stage in the language learning process (Mondria \& Wiersma, 2004) and children's first and second language vocabulary development move from receptive to expressive (Yong, 1999). Besides, this result was parallel with the findings of Zhong (2006) who put forward that receptive vocabulary develops much faster than productive vocabulary during the earlier stages of first and second language learning.

On the other hand, when compared to the pretest scores of receptive vocabulary (i.e., learner recognition of the form and meaning of a word encountered in hearing) and productive vocabulary (i.e., learner retrieval of the form and meaning of an item and its production for expression in speaking) (see Table 1), both experimental and control groups showed complete failure in the expressive vocabulary part $(\mathrm{M}: 0,0)$ although they demonstrated partial success in the receptive vocabulary part (M:1,75, M:1,7). The underlying reasons might be due to the fact that children could guess and understand some English words easily because they were cognates which meant they were similar in pronunciation in the two languages but different in their spelling. For example, some words in the vocabulary test such as police wagon, helicopter and motorcycle are the cognate words in Turkish and English languages. The study conducted by Bastin (2000), Malkiel (2009), Schelesinger and Malkiel (2005) who asserted that cognates are helpful, not only for novices but also for highly interpreters and cognates have positive effect on the speed of word recognition verified the finding of this study.

Specifically, the results of PREEXP scores $(\mathrm{M}=0,0)$ which means children from both experimental $(\mathrm{M}=0,0)$ and control groups $(\mathrm{M}=0,0)$ didn't give any correct answer to the questions in the checklist verify the finding that initial L2 knowledge of children in preschools especially in public preschools in Turkey is very scarce or none (Sığırtmaç, 2009). This is expected considering the fact that English curriculum for early childhood education is non- 
existent in Turkey and children don't have any English background. This might also be related with the fact that MONE didn't and don't provide the formal teaching of English in public preschools prior to primary education (Zorba \& Tosun, 2011).

Table 2. T-test Results of Receptive Vocabulary Test

\begin{tabular}{lllllllll}
\hline Variables & \multicolumn{2}{l}{$\begin{array}{l}\text { Levene's Test for } \\
\text { Equality of Variances }\end{array}$} & \multicolumn{3}{c}{$\begin{array}{c}\text { T-test for } \\
\text { Equality of Means }\end{array}$} \\
\hline POSTREC & F & Sig. & t. & df & $\begin{array}{c}\text { Sig. } \\
(2-t a i l e d)\end{array}$ & MD & Std. ED \\
& & & & & & & \\
& 6,903 &, 012 & 12,46 & 46 &, 000 & 2,45 &, 197 \\
& & & 12,46 & 35,67 &, 000 & 2,45 &, 197 \\
\hline
\end{tabular}

The table 2 showed that there was a statistically significant difference between the experimental and control group confirming the effect of English talking toy on improving VYL's receptive vocabulary knowledge. In other words, the class instructed with English talking toys performed better on receptive vocabulary than the class instructed with flashcards.

Table 3. T-test Results of Expressive Vocabulary Test

\begin{tabular}{|c|c|c|c|c|c|c|c|}
\hline \multirow{2}{*}{$\begin{array}{l}\text { Variables } \\
\text { POSTEXP }\end{array}$} & \multicolumn{3}{|c|}{$\begin{array}{l}\text { Levene's Test for } \\
\text { Equality of Variances }\end{array}$} & \multicolumn{4}{|c|}{$\begin{array}{c}\text { T-test for } \\
\text { Equality of Means }\end{array}$} \\
\hline & $\mathrm{F}$ & Sig. & t. & $\mathrm{df}$ & $\begin{array}{c}\text { Sig. } \\
\text { (2-tailed) }\end{array}$ & MD & Std. ED \\
\hline & \multirow[t]{2}{*}{2,868} & 097 & 10,56 & 46 & ,000 & 3,12 & ,295 \\
\hline & & & 10,56 & 35,67 & ,000 & 3,12 & ,295 \\
\hline
\end{tabular}

Table 3 revealed that there was a significant difference between the groups with regard to the VYL's expressive vocabulary knowledge. Consequently, the results of this study showed that the use of English talking toy as teaching material had positive effects on receptive and expressive vocabulary learning of VYL.

Table 4. Manova Results

\begin{tabular}{|c|c|c|c|c|c|c|}
\hline & $\begin{array}{l}\text { Wilks' } \\
\text { Lambada }\end{array}$ & $\mathbf{F}$ & $\begin{array}{c}\text { Hypothesis } \\
\text { df }\end{array}$ & $\begin{array}{c}\text { Error } \\
\text { df }\end{array}$ & Sig. & $\begin{array}{c}\text { Eta } \\
\text { Squared }\end{array}$ \\
\hline \multirow[t]{2}{*}{ Intercept } & 0,02 & 823 & 2 & 45 &, 000 & ,97 \\
\hline & Erker & ilt $2 \cdot 5$ & $\begin{array}{l}\text { tr1 Dergisi } \\
12 \cdot \text { Mayls }\end{array}$ & $\begin{array}{l}\text { ournal of } \mathrm{E} \\
\text { Jolume } 2 \cdot \mathrm{I}\end{array}$ & $\begin{array}{l}\text { Childho } \\
2 \cdot \text { May }\end{array}$ & tudies \\
\hline
\end{tabular}


Gender

$\begin{array}{llllll}0,96 & , 773 & 2 & 45 & , 46\end{array}$

Considering the findings of the previous studies trying to identify the positive effects of gender on foreign language vocabulary learning (Piske, Mackay \& Flege, 2001), it was seen in Table 4 that the findings of gender analysis in this study were not compatible with them. This was the indicative of VYL's gender didn't have any influence on their receptive and expressive vocabulary learning.

As far as the researcher observed during the treatment, although the participants hadn't been exposed to English at home and in the school so far, their enthusiasm, attitudes and success in recalling and producing newly taught words in foreign language highlighted a need to start English instruction at earlier ages such as in early childhood education. Like many previous studies (Muro \& Kottman, 1995; Harley, 1995; Krashen, 1989; Kırkgöz, 2009), this study showed that the younger the child is when learning a language, the closer the process comes to learning. Therefore, in a country such as Turkey where teaching and learning English is highly encouraged and English is the indispensable part of the curriculum, it can be suggested that English language teaching should begin earlier than second grade with age-appropriate methods and materials.

\section{DISCUSSION AND CONCLUSION}

This study shows a different dimension of English talking toys by integrating them into teaching materials that can be used in VYL's foreign language class. The language input in a language classroom should be comprehensible to students so that learners can understand the material, work on it, and turn it into output (Krashen, 1998). The findings of the study demonstrate that both teaching materials (i.e., flashcards and talking toys) can be comprehensible input because they make VYL achieve the desired learning outcomes successfully. However, to use English talking toys to teach basic English vocabulary to VYL leads more vocabulary learning than teaching vocabulary with flashcards at the recognition and production stage. Consequently, VYL in the experimental group are much better in their receptive and productive vocabulary in English learning process when English talking toy is used as teaching material. The possible reasons of this might be the fact that even though flashcards are visual materials that merely provide VYL to associate the meaning with the vocabulary and structure, talking toys are audiovisual materials including certain senses such as hearing, seeing and touching address to learner's visual/spatial, body/kinesthetic and musical/rhythmic intelligences and thus, yield to fostering a positive environment as well as lengthening their attention span (Ekşi, 2009). 
The results seem to be parallel with the findings of the study carried out by Nilawati (2009) who indicates the effectiveness of the puppet toys on vocabulary teaching in English. Similar to these results, Linse (2005) also find out that toys and brightly colored visuals are quite effective in keeping them engaged in activities about vocabulary teaching in English. As a result, the positive results of this study can be encouraging for teachers to give place to English talking toy in VYL language classrooms.

Additionally, related to the findings of the piloting studies, the vocabulary checklist test designed by the researcher to measure preschooler's English vocabulary receptively and productively on a specific topic might contribute to foreign language testing in early childhood education. Epstein (2004) emphasizes the child assessment is a vital and growing component of early childhood education. This vocabulary test can be used as a tool not only in evaluating the effectiveness of the language teaching materials but also in understanding and supporting VYL's receptive and expressive vocabulary knowledge in a foreign language.

Apart from these, the findings of this study can be useful for a large group of early childhood teachers and administrators who know the importance of teaching English at earlier ages and feel need new effective ways to teach it and parents who are the first and the most important educators of their children. In addition to this, it can be beneficial to support the idea of integrating language education and entertainment with the help of English talking toy during preschool period and thus, it provides the improvement of preschool children's receptive and expressive vocabulary knowledge and positive attitudes toward English learning at a certain level.

This study can also serve a guideline to the educators who give importance to active learning more than rote-learning. They can get benefit from this study by replacing or combining their traditional teaching techniques and materials such as flashcards with the interesting and educational ones. Moreover, MONE and curriculum developers should be aware of the necessity of an English curriculum for VYL who have distinctive learning features and different needs and interests. They also need to be aware of the same materials and methods used in English learning to adult or YL cannot work efficiently for VYL and then, it can be suggested to integrate this educational toy talking in target language to this curriculum.

Lastly, the parents can make use of the findings of the study in the process of selecting educational toys for their children. They can prefer talking toys that encourage them to learn 
some English words with the correct pronunciation and increase their positive attitudes toward learning English in the informal environment.

There are a few limitations in this study that need to be pointed out such as the low number of participants and representativeness of the participants which limit the generalization of the results. Despite the shortcomings mentioned above, the present study provides English teachers working in preschool level to an alternative thinking and a teaching material to create more fun and effective English lessons for VYL. Related to the findings of the study, it can also be recommended that as well as common teaching materials such as flashcards, photographs and realias, educational toys including talking toys should be integrated into the lessons to teach and practice basic English vocabulary effectively.

\section{REFERENCES}

Bastin, G. (2000): Evaluating beginners' re-expression and creativity: A positive approach. The Translator: Studies in Intercultural Communication, 6(2):231-245.

Cameron, L. (2005). Teaching languages to young learners. United Kingdom: Cambridge University Press

Celce-Murcia, M., \& Rosensweig F. (1979). Teaching vocabulary in the ESL classroom. In Celce- Murcia, M. and M. McIntosh (Eds.), Teaching English as a second or foreign language (pp. 241-252). USA: Newbury House.

Demirel Ö. (2004). ELT methodology. Ankara: Pegema.

Ekşi, G. (2009). Multiple short story activities for very young learners with multiple tastes. EKEV Akademi Dergisi, 13(40), 51-68.

Epstein, A. S., Schweinhart, L. J., DeBruin-Parecki, A., \& Robin, K. B. (2004). Preschool assessment: A guide to developing a balanced approach. New Brunswick, NJ: National Institute for Early Childhood Research

Ersöz, A. (2007). Teaching English to young learners. Ankara: EDM Publishing

Espinosa, L. M. \& Lopez, M. (2007). Assessment considerations for young English language learners across different levels of accountability. Philadelphia: National Early Childhood Accountability Task Force

Harley, B. (1995). Introduction: the lexicon in the second language research. In B. Harley (Eds.), Lexical issues in language learning (pp. 1-28). Amsterdam: John Benjamins.

Harmer, J. (2007). The practice of English language teaching. Harlow: Longman.

Hopewell, K., McLaughlin, T. F., \& Derby, K. M. (2011). The effects of reading racetracks with direct instruction flashcards and a token system on sight word acquisition for two primary students with severe conduct disorders. Electronic Journal of Research in 
Educational Psychhopewellology, 9(2). Retrieved from

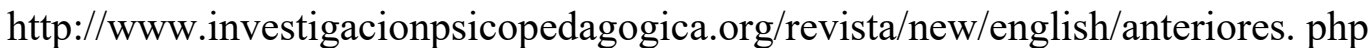

Keddle, J. (1997). The Inbetweens. Teaching English Spring (5), OUP. 15-19

Kırkgöz, Y. (2009). Globalization and English language policy in Turkey. Educational Policy, 23(5), 663-684

Krashen, S. (1989). We acquire vocabulary and spelling by reading: Additional evidence for the input hypothesis. The Modern Language Journal, 7(3), 440464.

Krashen, S. D. (1981). Second language acquisition and second language learning. Oxford: Pergamon

Krashen, S. D. (1998). Comprehensible output? System, 26, 175-182

Laufer, B. \& Hulstijn, J. (2001). Incidental vocabulary acquisition in a second language: the construct of task-induced involvement. Applied Linguistics, 22(1), 1-26.

Linse, C. T. (2005). Practical English language teaching: Young learners. United States: McGraw-Hill Publishing.

Malkiel, B. (2009). Translation as a decision process: Evidence from cognates. Babel, 55(3), 228-243

Melka, F. (1997). Receptive vs. productive aspects of vocabulary. In Schmitt and McCharty (Eds.), Vocabulary: Description, acquisition and pedagogy (pp. 84-102). Cambridge: Cambridge University Press

Mondria, J., \& Wiersma, B. (2004). Receptive, productive, and receptive \& productive second language learning vocabulary learning: What difference does it make? In Bogaards, P. (Ed.), Vocabulary in a second language. Selection, acquisition and testing. (pp. 79-88). Philadelphia, PA USA: John Benjamin Publishing Company

Milli Eğitim Bakanlığg, Talim ve Terbiye Kurulu Başkanlığı. (2006). Okul öncesi eğitim program1. Retrieved May, 19, 2016, from http://www.meb.gov.tr

Milli Eğitim Bakanlığı, Talim ve Terbiye Kurulu Başkanlığı. (2008). İlköğretim İngilizce dersi öğretim programı. Retrieved May, 19, 2016, from http://www.meb.gov.tr

Milli Eğitim Bakanlığı, Talim ve Terbiye Kurulu Başkanlığı. (2016). Okul Öncesi İngilizce dersi öğretim programı. Retrieved May, 19, 2017, from http://www.meb.gov.tr

Muro, J. J., \& Kottman, T. (1995). Guidance and counseling in the elementary and middle schools. Iowa: Brown and Benchmark.

Nation, P. (1990). Teaching and learning vocabulary. New York: Heinle and Heinle.

Nilawati, C. S. (2009). The effectiveness of teaching vocabulary by using puppet at elementary school students. Retrieved from ProQuest Dissertations \& Theses.

Piske, T., MacKay, I., \& Flege, J. (2001). Factors affecting degree of foreign accent in an L2: A review. Journal of Phonetics, 29, 191-215. 
Rivera, M. (2009). The powerful effect of play in a child's education. In M. Rivera (Eds.), The Hispanic outlook in higher education (pp. 20-21). Paramus.

Schmitt N., \& McCharty, M. (1997). Vocabulary: Description, acquisition and pedagogy (pp. 84-102). Cambridge: Cambridge University Press.

Scott, W., \& Ytreberg, L. H. (1990). Teaching English to children. London: Longman.

Sert, N. (2004). Quality in early foreign language learning at pre-school level. Eurasian Journal of Educational Research, 12, 12-30.

Shlesinger, M., \& Malkiel, B. (2005). Comparing modalities: cognates as a case in point. Across Languages and Cultures. A Multidisciplinary Journal for Translation and Interpreting Studies, 6(2), 143-172

Sığırtmaç, A. (2009). Teaching English in early childhood. Inonu University Journal of the Faculty of Education, 10(1), 102-122.

Singer, D. G., \& Singer, J. L. (2005). Imagination and play in the electronic age. Cambridge, MA: Harvard University Press.

Siraj-Blatchford, I., \& Clarke, P. (2000). Supporting identity, diversity and language in the early years. Open University Press: Bucks.

Tokuhama-Espinosa, T. (2003). The multilingual mind: Questions by, for, and about people living with many languages. Westport, CT: Praeger Press

Yong, W. (1999). Teaching collocations for productive vocabulary development. Annual Meeting of the Teachers of English to Speakers of Other Languages. New York, NY: Microfiche Collection of Clearinghouse Documents

Zhong, H. (2011). Learning a word: From receptive to expressive vocabulary use. The Asian Conference on Language Learning 2011, 116-126.

Zorba, G. B., \& Tosun, S. (2011). Enriching kindergarten learners' English by using language portfolio and additional instructional materials. Contemporary Online Language Education Journal, 1(2), 35-43. 